\title{
GAMBARAN ERUPSI GIGI PERMANEN PADA ANAK SINDROM DOWN USIA 10 - 16 TAHUN DI SEKOLAH LUAR BIASA KABUPATEN JEMBER
}

\author{
Loly Anastasya Sinaga ${ }^{\mathrm{a}}$, Dwi Kartika Apriyono ${ }^{\mathrm{b}}$, Masniari Novita ${ }^{\mathrm{b}}$ \\ ${ }^{\text {a) }}$ Fakultas Kedokteran Gigi, Universitas Jember

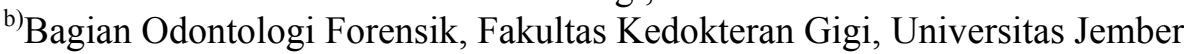 \\ E-mail: 1olysinaga2@gmail.com
}

\begin{abstract}
Background: Down Syndrome is a genetic disorder that occurs because of chromosome 21 has three chromosome (trisomy 21). The extra chromosome changes the genetic balance, physical characteristic, intellectual abilities, and physiological body function. Tooth eruption in Down Syndrome children typically delayed in both the timing and sequence of eruption up to two or three years. Objective: To observe the permanent teeth eruption in Down syndrome children at age 10-16 years old, boys and girls in Special Needs School in Jember. Materials and Methods: This research was a descriptive study with 7 subjects. Each subject was examined then calculated teeth that had emerged or functionally eruption with articualting paper. Result and Conclusion: Both permanent teeth that is still partially erupted tooth (emerged/ EM) and had erupted perfectly (functionally eruption/FE) delayed in eruption in Down Syndrome boys and girls at age 10-16 years old.
\end{abstract}

Keywords: Down Syndrome, Emerged of Permanent Teeth, and Functionally Eruption of Permanent Teeth.

\section{Pendahuluan}

Down Syndrome atau Sindrom Down merupakan kelainan genetik yang terjadi karena kromosom 21 memiliki tiga kromosom (trisomi 21) [1]. Sindrom Down terjadi pada sekitar 1 dari 700 kelahiran bayi dan lebih sering terjadi pada ibu hamil berusia di atas 35 tahun [2].

Kelebihan kromosom pada penderita Sindrom Down akan mengubah keseimbangan genetik tubuh dan mengakibatkan perubahan karakteristik fisik dan kemampuan intelektual, serta gangguan dalam fungsi fisiologi tubuh [3]. Manifestasi pada gigi dan mulut Sindrom Down adalah keterlambatan perkembangan dan erupsi gigi geligi, hipodonsia, mikrodonsia, dilaserasi akar, maloklusi klas III, open bite anterior, fissured tongue, maksila yang kecil dan tingginya insiden penyakit periodontal [4].

Erupsi gigi didefinisikan sebagai pergerakan atau proses munculnya gigi ke arah rongga mulut yang dimulai sejak gigi berada di dalam tulang alveolar [5]. Gigi dikatakan muncul (emerged) jika sebagian gigi sudah tampak atau sudah menembus gusi tetapi belum menyentuh dataran oklusal atau belum ada kontak dengan gigi antagonisnya. Gigi dikatakan erupsi fungsional (functionally eruption) jika sudah mencapai dataran oklusal atau sudah ada kontak dengan gigi antagonisnya [6].

Erupsi gigi pada anak Sindrom Down biasanya mengalami keterlambatan erupsi baik pada waktu dan urutan erupsi giginya terkhusus pada gigi permanen anterior dan molar pertama permanen rahang atas dan rahang bawah [7]. Sindrom Down mengalami keterlambatan erupsi gigi dua sampai tiga tahun daripada normal [8].

Tujuan penelitian ini adalah untuk mengetahui gambaran erupsi gigi permanen pada anak Sindrom Down di Sekolah Luar Biasa (SLB) Kabupaten Jember.

\section{Metode Penelitian}

Penelitian ini merupakan jenis penelitian deskriptif. Penelitian dilakukan di SLB-C Negeri Patrang, SLB-C TPA, dan SLB-C Yayasan Pendidikan dan Asuhan Bintoro Jember yang dilaksanakan pada bulan November 2016 sampai dengan bulan Januari 2017.

Subjek penelitian berjumlah 7 orang dan pada setiap subjek dilakukan pemeriksaan rongga mulut dengan menggunakan kaca mulut nomor 3 dan nomor 4. Kemudian subjek diinstruksikan untuk menggigit articulating paper. Setelah itu, dilihat dan diperiksa teraan 
pada articulating paper dan pada gigi subjek, gigi apa saja yang sudah mengalami kontak dengan gigi antagonisnya dengan memperhatikan gigi yang emerged (EM) dan functionally erupted (FE). Selanjutnya, hasil yang diperoleh dibandingkan dengan Tabel Shaweesh (2012). Tabel Shaweesh (2012) menjelaskan tentang usia EM dan FE gigi permanen pada anak laki-laki normal dan anak perempuan normal. Hasil penelitian dibandingkan dengan Tabel Shaweesh berdasarkan usia kronologis subjek. Gigi yang dibandingkan adalah gigi yang harusnya sudah erupsi, baik EM ataupun FE sesuai dengan usia kronologis subjek tersebut. Akumulasi data dasar dalam bentuk deskripsi yang disajikan dalam bentuk tabel dan diagram batang.

\section{Hasil Penelitian}

Dari hasil penelitian, didapatkan ratarata selisih umur gigi permanen pada anak lakilaki dan perempuan Sindrom Down SLB-C Negeri Patrang, SLB-C TPA, dan SLB-C Yayasan Pendidikan dan Asuhan Bintoro Jember yang ditampilkan pada Tabel 1 dan Tabel 2.

Tabel 1 Hasil pengamatan erupsi gigi dan usia kronologis pada anak laki-laki Sindrom Down subjek 1

\begin{tabular}{lllll}
\hline Gigi & $\begin{array}{l}\text { Kondisi } \\
\text { Gigi }\end{array}$ & $\begin{array}{l}\text { Usia } \\
\text { Kronologis } \\
\text { Subjek 1 } \\
\text { (Tahun) }\end{array}$ & $\begin{array}{l}\text { Tabel } \\
\text { Shaweesh } \\
\text { Umur } \\
\text { EM/FE } \\
\text { (Tahun) }\end{array}$ & Keterangan \\
\hline 12 & EM & 10,22 & 8,45 & $\begin{array}{l}\text { Terlambat } \\
\text { erupsi }\end{array}$ \\
\hline 22 & EM & 10,22 & 8,45 & $\begin{array}{l}\text { Terlambat } \\
\text { erupsi }\end{array}$ \\
\hline 31 & EM & 10,22 & 6,49 & $\begin{array}{l}\text { Terlambat } \\
\text { erupsi }\end{array}$ \\
\hline 32 & EM & 10,22 & 7,50 & $\begin{array}{l}\text { Terlambat } \\
\text { erupsi }\end{array}$ \\
\hline 41 & EM & 10,22 & 6,48 & $\begin{array}{l}\text { Terlambat } \\
\text { erupsi }\end{array}$ \\
\hline 42 & EM & 10,22 & 7,51 & $\begin{array}{l}\text { Terlambat } \\
\text { erupsi }\end{array}$ \\
\hline
\end{tabular}

Berdasarkan Tabel 1, subjek 1 dengan usia kronologis 10,22 tahun memiliki 6 gigi yang masih EM (emerged) atau tampak sebagian. Keenam gigi tersebut seharusnya pada usia 10,22 tahun sudah mengalami FE (functionally eruption) atau erupsi fungsional, tetapi pada kondisi sekarang masih mengalami EM. Hal ini berarti tidak sesuai dengan umur EM/FE pada Tabel Shaweesh. Ketidaksesuaian ini memiliki makna keenam gigi tersebut mengalami keterlambatan erupsi gigi.

Tabel 2 Hasil pengamatan erupsi gigi dan usia kronologis pada anak laki-laki Sindrom Down subjek 2

\begin{tabular}{lllll}
\hline Gigi & $\begin{array}{l}\text { Kondisi } \\
\text { Gigi }\end{array}$ & $\begin{array}{l}\text { Usia } \\
\text { Kronologis } \\
\text { Subjek 2 } \\
\text { (Tahun) }\end{array}$ & $\begin{array}{l}\text { Tabel } \\
\text { Shaweesh } \\
\text { Umur } \\
\text { EM/FE } \\
\text { (Tahun) }\end{array}$ & Keterangan \\
\hline 21 & EM & 10,70 & 7,26 & $\begin{array}{l}\text { Terlambat } \\
\text { erupsi }\end{array}$ \\
\hline 31 & EM & 10,70 & 6,49 & $\begin{array}{l}\text { Terlambat } \\
\text { erupsi }\end{array}$ \\
\hline 32 & EM & 10,70 & 7,50 & $\begin{array}{l}\text { Terlambat } \\
\text { erupsi }\end{array}$ \\
\hline 41 & EM & 10,70 & 6,48 & $\begin{array}{l}\text { Terlambat } \\
\text { erupsi }\end{array}$ \\
\hline 42 & EM & 10,70 & 7,51 & $\begin{array}{l}\text { Terlambat } \\
\text { erupsi }\end{array}$ \\
\hline
\end{tabular}

Subjek 2 memiliki 5 gigi yang mengalami EM. Pada Tabel Shaweesh sesuai dengan usia kronologis subjek 2, yaitu 10,70 tahun seharusnya kelima gigi tersebut sudah FE. Berdasarkan hasil pengamatan, erupsi gigi pada subjek 2 mengalami keterlambatan. Hal ini dikarenakan tidak sesuai dengan umur EM/FE pada Tabel Shaweesh.

Tabel 3 Hasil pengamatan erupsi gigi dan usia kronologis pada anak laki-laki Sindrom Down subjek 3

\begin{tabular}{lllll}
\hline Gigi & $\begin{array}{l}\text { Kondisi } \\
\text { Gigi }\end{array}$ & $\begin{array}{l}\text { Usia } \\
\text { Kronologis } \\
\text { Subjek 3 } \\
\text { (Tahun) }\end{array}$ & $\begin{array}{l}\text { Tabel } \\
\text { Shaweesh } \\
\text { Umur } \\
\text { EM/FE } \\
\text { (Tahun) }\end{array}$ & Keterangan \\
\hline 17 & EM & 15,33 & 12,61 & $\begin{array}{l}\text { Terlambat } \\
\text { erupsi }\end{array}$ \\
\hline 27 & EM & 15,33 & 12,60 & $\begin{array}{l}\text { Terlambat } \\
\text { erupsi }\end{array}$ \\
\hline 37 & EM & 15,33 & 12,15 & $\begin{array}{l}\text { Terlambat } \\
\text { erupsi }\end{array}$ \\
\hline 47 & EM & 15,33 & 12,19 & $\begin{array}{l}\text { Terlambat } \\
\text { erupsi }\end{array}$ \\
\hline
\end{tabular}

Pada subjek ketiga dengan usia kronologis 15,33 tahun dapat dilihat bahwa gigi 17, 27, 37, dan 47 masih mengalami EM. Berdasarkan Tabel Shaweesh, gigi 
tersebut seharusnya mengalami EM pada usia kisaran 12 tahun dan sudah mengalami FE pada usia sekitar 13 tahun. Hal ini berarti erupsi gigi pada subjek 3 tidak sesuai dengan umur EM/FE pada Tabel Shaweesh, artinya mengalami keterlambatan erupsi gigi.

Tabel 4 Hasil pengamatan erupsi gigi dan usia kronologis pada anak laki-laki Sindrom Down subjek 4

\begin{tabular}{|c|c|c|c|c|}
\hline Gigi & $\begin{array}{l}\text { Kondisi } \\
\text { Gigi }\end{array}$ & $\begin{array}{l}\text { Usia } \\
\text { Kronologis } \\
\text { Subjek 4 } \\
\text { (Tahun) }\end{array}$ & $\begin{array}{l}\text { Tabel } \\
\text { Shaweesh } \\
\text { Umur } \\
\text { EM/FE } \\
\text { (Tahun) }\end{array}$ & Keterangan \\
\hline 13 & EM & 16,85 & 11,56 & $\begin{array}{l}\text { Terlambat } \\
\text { erupsi }\end{array}$ \\
\hline 15 & EM & 16,85 & 11,37 & $\begin{array}{l}\text { Terlambat } \\
\text { erupsi }\end{array}$ \\
\hline 17 & EM & 16,85 & 12,61 & $\begin{array}{l}\text { Terlambat } \\
\text { erupsi }\end{array}$ \\
\hline 23 & EM & 16,85 & 11,57 & $\begin{array}{l}\text { Terlambat } \\
\text { erupsi }\end{array}$ \\
\hline 25 & EM & 16,85 & 11,21 & $\begin{array}{l}\text { Terlambat } \\
\text { erupsi }\end{array}$ \\
\hline 27 & EM & 16,85 & 12,60 & $\begin{array}{l}\text { Terlambat } \\
\text { erupsi }\end{array}$ \\
\hline 35 & EM & 16,85 & 11,57 & $\begin{array}{l}\text { Terlambat } \\
\text { erupsi }\end{array}$ \\
\hline 37 & EM & 16,85 & 12,15 & $\begin{array}{l}\text { Terlambat } \\
\text { erupsi }\end{array}$ \\
\hline 43 & EM & 16,85 & 10,63 & $\begin{array}{l}\text { Terlambat } \\
\text { erupsi }\end{array}$ \\
\hline 45 & EM & 16,85 & 11,73 & $\begin{array}{l}\text { Terlambat } \\
\text { erupsi }\end{array}$ \\
\hline 47 & EM & 16,85 & 12,19 & $\begin{array}{l}\text { Terlambat } \\
\text { erupsi }\end{array}$ \\
\hline
\end{tabular}

Subjek penelitian berjenis kelamin lakilaki ada 4 orang. Subjek keempat dengan jenis kelamin laki-laki yang berusia 16,85 tahun memiliki 11 gigi yang masih EM. Pada anak normal dengan usia 16,85 tahun, seharusnya semua gigi tersebut sudah FE, sedangkan pada subjek 4 masih mengalami EM. Hal ini berarti erupsi gigi pada subjek 4 mengalami keterlambatan.
Tabel 5 Hasil pengamatan erupsi gigi dan usia kronologis pada anak perempuan Sindrom Down subjek 5

\begin{tabular}{|c|c|c|c|c|}
\hline Gigi & $\begin{array}{l}\text { Kondisi } \\
\text { Gigi }\end{array}$ & $\begin{array}{l}\text { Usia } \\
\text { Kronologis } \\
\text { Subjek } 5 \\
\text { (Tahun) }\end{array}$ & $\begin{array}{l}\text { Tabel } \\
\text { Shaweesh } \\
\text { Umur } \\
\text { EM/FE } \\
\text { (Tahun) }\end{array}$ & Keterangan \\
\hline 12 & EM & 10,95 & 8,07 & $\begin{array}{l}\text { Terlambat } \\
\text { erupsi }\end{array}$ \\
\hline 14 & EM & 10,95 & 10,01 & $\begin{array}{l}\text { Terlambat } \\
\text { erupsi }\end{array}$ \\
\hline 15 & EM & 10,95 & 10,85 & $\begin{array}{l}\text { Terlambat } \\
\text { erupsi }\end{array}$ \\
\hline 24 & EM & 10,95 & 10,07 & $\begin{array}{l}\text { Terlambat } \\
\text { erupsi }\end{array}$ \\
\hline 25 & EM & 10,95 & 10,86 & $\begin{array}{l}\text { Terlambat } \\
\text { erupsi }\end{array}$ \\
\hline 32 & EM & 10,95 & 7,36 & $\begin{array}{l}\text { Terlambat } \\
\text { erupsi }\end{array}$ \\
\hline 33 & EM & 10,95 & 9,84 & $\begin{array}{l}\text { Terlambat } \\
\text { erupsi }\end{array}$ \\
\hline 34 & EM & 10,95 & 10,06 & $\begin{array}{l}\text { Terlambat } \\
\text { erupsi }\end{array}$ \\
\hline 35 & EM & 10,95 & 10,95 & $\begin{array}{l}\text { Erupsi } \\
\text { normal }\end{array}$ \\
\hline 42 & EM & 10,95 & 7,43 & $\begin{array}{l}\text { Terlambat } \\
\text { erupsi }\end{array}$ \\
\hline 43 & EM & 10,95 & 9,84 & $\begin{array}{l}\text { Terlambat } \\
\text { erupsi }\end{array}$ \\
\hline 44 & EM & 10,95 & 10,12 & $\begin{array}{l}\text { Terlambat } \\
\text { erupsi }\end{array}$ \\
\hline
\end{tabular}

Tabel 5 menunjukkan 12 gigi yang mengalami EM pada subjek 5 dengan usia kronologis 10,95 tahun. Berdasarkan hasil penelitian terdapat 1 gigi yang mengalami erupsi normal pada subjek 5, yaitu gigi 35. Erupsi gigi 35 dikatakan normal karena waktu erupsinya sesuai dengan umur EM pada Tabel Shaweesh, sedangkan pada 11 gigi yang lainnya mengalami keterlambatan erupsi karena pada usia 10,95 tahun seharusnya gigi tersebut sudah mengalami FE sementara pada subjek ini masih mengalami EM. 
Tabel 6 Hasil pengamatan erupsi gigi dan usia kronologis pada anak perempuan Sindrom Down subjek 6

\begin{tabular}{|c|c|c|c|c|}
\hline Gigi & $\begin{array}{l}\text { Kondisi } \\
\text { Gigi }\end{array}$ & $\begin{array}{l}\text { Usia } \\
\text { Kronologis } \\
\text { Subjek 6 } \\
\text { (Tahun) }\end{array}$ & $\begin{array}{l}\text { Tabel } \\
\text { Shaweesh } \\
\text { Umur } \\
\text { EM/FE } \\
\text { (Tahun) }\end{array}$ & Keterangan \\
\hline 12 & EM & 12,86 & 8,07 & $\begin{array}{l}\text { Terlambat } \\
\text { erupsi }\end{array}$ \\
\hline 14 & EM & 12,86 & 10,01 & $\begin{array}{l}\text { Terlambat } \\
\text { erupsi }\end{array}$ \\
\hline 15 & EM & 12,86 & 11,00 & $\begin{array}{l}\text { Terlambat } \\
\text { erupsi }\end{array}$ \\
\hline 17 & EM & 12,86 & 12,32 & $\begin{array}{l}\text { Terlambat } \\
\text { erupsi }\end{array}$ \\
\hline 24 & EM & 12,86 & 10,07 & $\begin{array}{l}\text { Terlambat } \\
\text { erupsi }\end{array}$ \\
\hline 27 & EM & 12,86 & 12,35 & $\begin{array}{l}\text { Terlambat } \\
\text { erupsi }\end{array}$ \\
\hline 33 & EM & 12,86 & 9,84 & $\begin{array}{l}\text { Terlambat } \\
\text { erupsi }\end{array}$ \\
\hline 34 & EM & 12,86 & 10,06 & $\begin{array}{l}\text { Terlambat } \\
\text { erupsi }\end{array}$ \\
\hline 35 & EM & 12,86 & 11,11 & $\begin{array}{l}\text { Terlambat } \\
\text { erupsi }\end{array}$ \\
\hline 37 & EM & 12,86 & 11,84 & $\begin{array}{l}\text { Terlambat } \\
\text { erupsi }\end{array}$ \\
\hline 43 & EM & 12,86 & 9,84 & $\begin{array}{l}\text { Terlambat } \\
\text { erupsi }\end{array}$ \\
\hline 44 & FE & 12,86 & 10,90 & $\begin{array}{l}\text { Erupsi } \\
\text { normal }\end{array}$ \\
\hline 45 & FE & 12,86 & 11,61 & $\begin{array}{l}\text { Erupsi } \\
\text { normal }\end{array}$ \\
\hline 47 & EM & 12,86 & 11,86 & $\begin{array}{l}\text { Terlambat } \\
\text { erupsi }\end{array}$ \\
\hline
\end{tabular}

Subjek berusia 12,86 tahun di atas memiliki 12 gigi yang masih mengalami EM dan 2 gigi yang sudah mengalami FE. Pada keterangan gigi 44 dan 45 adalah erupsi normal, artinya erupsi gigi tersebut sesuai dengan umur FE pada Tabel Shaweesh, meskipun pada subjek 6 tidak diketahui kapan pertama kali kedua gigi tersebut mengalami FE. Pada 12 gigi lainnya dikatakan terlambat erupsi karena waktu erupsinya tidak sesuai dengan umur gigi EM pada Tabel Shaweesh.
Tabel 7 Hasil pengamatan erupsi gigi dan usia kronologis pada anak perempuan Sindrom Down subjek 7

\begin{tabular}{|c|c|c|c|c|}
\hline Gigi & $\begin{array}{l}\text { Kondisi } \\
\text { Gigi }\end{array}$ & $\begin{array}{l}\text { Usia } \\
\text { Kronologis } \\
\text { Subjek } 7 \\
\text { (Tahun) }\end{array}$ & $\begin{array}{l}\text { Tabel } \\
\text { Shaweesh } \\
\text { Umur } \\
\text { EM/FE } \\
\text { (Tahun) }\end{array}$ & Keterangan \\
\hline 17 & FE & 16,85 & 12,98 & $\begin{array}{l}\text { Erupsi } \\
\text { normal }\end{array}$ \\
\hline 27 & FE & 16,85 & 16,97 & $\begin{array}{l}\text { Erupsi } \\
\text { normal }\end{array}$ \\
\hline
\end{tabular}

Pada subjek ketujuh yang berusia 16,85 tahun memiliki gigi 17 dan 27 yang sudah mengalami FE. Hal ini sesuai dengan umur FE pada Tabel Shaweesh, meskipun tidak diketahui kapan pertama kali kedua gigi tersebut mengalami FE. Artinya, gigi 17 dan gigi 27 dapat dikatakan erupsi giginya adalah normal.

\section{Pembahasan}

Sindrom Down merupakan salah satu kondisi patologis kongenital dimana terdapat keterlambatan erupsi gigi [9]. Keterlambatan erupsi gigi ini disebabkan oleh mutasi activin receptor-like kinase 2 (ALK2) pada Sindrom Down. ALK2 merupakan reseptor tipe I bone morphogenetic protein (BMP) dan berperan dalam signaling BMP [10]. Gen BMP merupakan gen yang berperan dalam pembentukan tulang dan tulang rawan [11].

Erupsi gigi memerlukan resorpsi tulang dan pembentukan tulang. Berdasarkan penelitian oleh Wise dan Yao (2006) dental follicle mengontrol resorpsi tulang alveolar dan pembentukan tulang yang dibutuhkan untuk erupsi melalui ekspresi gen yang berbeda pada dental follicle [12]. Dental follicle berperan dalam pengendalian molekuler pembentukan osteoklas (osteoklastogenesis) yang dibutuhkan untuk resorpsi tulang untuk membentuk jalannya erupsi [10].

Ekspresi gen penanda osteoklastogenesis untuk resorpsi tulang alveolar, yaitu gen RANKL, sedangkan ekspresi gen penanda pembentukan tulang, yaitu bone morphogenetic protein-2 (BMP-2). Ekspresi gen RANKL terjadi pada koronal dental follicle yang 
menyebabkan resorpsi tulang pada koronal dental follicle sehingga terbentuk jalannya erupsi gigi. Gen BMP-2 memiliki ekspresi yang lebih besar pada bagian basal dental follicle sehingga terjadi pembentukan tulang pada dasar tulang alveolar [13]. Pembentukan tulang pada basal dental follicle merupakan alasan adanya dorongan pada gigi yang hendak erupsi [10].

Gen BMP berikatan dengan reseptor BMP, yaitu ALK2 untuk transaktivasi [14]. Aktivasi BMPR membentuk kompleks heterodimerik yang kemudian ditranslokasi ke inti sel dan bertindak secara langsung dengan molekul lain untuk mengatur transkripsi gen target [15]. BMP-2 menginduksi berbagai jenis gen target, salah satunya adalah osteocalcin yang berperan dalam proses diferensiasi osteoblas [16].

Koordinasi antara pembentukan tulang dan resorpsi tulang dipertahankan oleh beberapa mekanisme gabungan antara osteoblas dan osteoklas [17]. RANKL dan CSF-1 adalah produk osteoblas dan penentu utama osteoklastogenesis. BMP berperan secara langsung maupun tidak langsung dalam osteoklastogenesis karena RANKL adalah produk osteoblas dan BMP menginduksi maturasi osteoblas, sehingga pada saat osteoblastogenesis diblokir oleh antagonis BMP maka osteoklastogenesis terganggu [18].

Mutasi ALK2 pada Sindrom Down diidentifikasi memiliki efek mengganggu dalam signaling BMP. Pada tes in vitro dan in vivo, ditemukan bahwa varian ALK2 telah mengurangi kapasitas induksi BMP dan memberi efek mengganggu yang bersifat ringan dalam signaling BMP [19]. Hal inilah yang menjadi penyebab terjadinya keterlambatan erupsi pada Sindrom Down.

Berdasarkan penelitian oleh Trotsenburg et al. (2006) bahwa semua individu dengan Sindrom Down akan mengalami hipotiroid pada saat lahir [20]. Adapun penyebab terjadinya hipotiroid kongenital pada bayi dengan Sindrom Down belum diketahui [21]. Anak dengan Sindrom Down memiliki kesempatan lebih tinggi untuk menunjukkan peningkatan thyroidstimulating hormone (TSH) yang ringan dengan tidak adanya penurunan tiroksin bebas (FT4) atau gejala hipotiroid yang jelas [22].
Pada individu dengan hipotiroid proses pergantian tulang menjadi terlambat, baik proses pembentukan dan resorpsi tulang [23]. Proses pembentukan tulang diperlambat dalam 50\% dari normal dan resorpsi tulang diperlambat dalam 40\% dari normal [24]. Keterlambatan ini disebabkan oleh penurunan aktivitas osteoblastik dan osteoklastik sehingga terjadi perpanjangan siklus remodeling tulang secara keseluruhan [25]. Hal ini menyebabkan proses pembentukan tulang dan resorpsi tulang alveolar pada dental follicle menjadi terlambat sehingga mempengaruhi proses erupsi gigi. Dari hasil penelitian ditemukan adanya perbedaan waktu erupsi gigi permanen antara anak laki-laki dan perempuan. Subjek laki-laki mengalami keterlambatan erupsi gigi lebih daripada subjek perempuan, terbukti dari jumlah gigi yang terlambat erupsi lebih banyak pada anak lakilaki daripada anak perempuan. Hasil penelitian ini sesuai dengan penelitian terdahulu oleh Jara et al. tahun 1953 di Cili yang menyatakan bahwa erupsi gigi pada perempuan lebih cepat daripada laki-laki. Hal ini terbukti dari jumlah gigi yang mengalami keterlambatan erupsi lebih banyak pada anak laki-laki Sindrom Down [26]. Erupsi gigi lebih cepat pada anak perempuan dikarenakan maturasi atau masa pubertas pada anak perempuan lebih cepat dibandingkan anak laki-laki [27].

Erupsi gigi dipengaruhi oleh sekresi hormon pertumbuhan. Hormon pertumbuhan meningkatkan kadar serum osteocalcin yang merupakan penanda pembentukan tulang [28]. Berdasarkan penelitian Torrado et al. tahun 1991, individu dengan Sindrom Down mengalami disfungsi hipotalamus dan menyebabkan defisiensi neurosekretori hormon pertumbuhan [29]. Defisiensi hormon pertumbuhan ini menyebabkan keterlambatan erupsi gigi daripada individu normal [30]. Berdasarkan penelitian Rose et al. tahun 1990, pada masa awal pubertas terjadi peningkatan sekresi hormon pertumbuhan yang lebih dulu pada perempuan daripada laki-laki [31]. Hal inilah yang menyebabkan erupsi gigi permanen 
pada anak perempuan lebih cepat daripada anak laki-laki.

Dari hasil penelitian yang didapat, pada anak Sindrom Down di SLB-C Negeri Patrang, SLB-C TPA, dan SLB-C Yayasan Pendidikan dan Asuhan Bintoro Jember dengan rentang usia 10-16 tahun baik pada jenis kelamin perempuan ataupun laki-laki terjadi keterlambatan erupsi gigi permanen. Hal ini terbukti dari waktu erupsi gigi subjek penelitian berdasarkan usia kronologis subjek yang berbeda dengan umur gigi EM/FE pada Tabel Shaweesh (2012). Penelitian senada yang dilakukan oleh Linden et al. (2017) menyatakan bahwa pada anak Sindrom Down terjadi keterlambatan emerged yang kemungkinan bukan dikarenakan oleh pertumbuhan gigi yang terlambat, akan tetapi karena proses lain yang berlangsung saat erupsi, seperti proses yang terganggu pada apikal dan oklusal saat erupsi gigi.

\section{Simpulan dan Saran}

Berdasarkan hasil penelitian yang telah dilakukan, maka dapat disimpulkan bahwa terdapat keterlambatan erupsi gigi permanen baik gigi yang masih erupsi sebagian (emerged / EM) ataupun sudah erupsi sempurna (functionally eruption/ FE) pada anak laki-laki dan perempuan penderita dan erupsi gigi pada anak laki-laki lebih lambat daripada anak perempuan penderita Sindrom Down di SLB-C Negeri Patrang, SLB-C TPA, dan SLB-C Yayasan Pendidikan dan Asuhan Bintoro Jember dengan rentang usia 10-16 tahun.

Saran yang dapat diberikan penulis, yaitu perlu dilakukan penambahan jumlah sampel sehingga didapatkan hasil yang lebih signifikan dan dapat dianalisis menggunakan uji statistik. Diharapkan juga dilakukan penelitian yang sama dengan pengamatan erupsi gigi pada subjek secara bertahap atau longitudinal serta penentuan subjek dengan menggunakan karyotyping.

\section{Daftar Pustaka}

[1] Pienaar, Dorothea. 2012. Music Therapy for Children with Down Syndrome: Perceptions of Caregivers in a Special School Setting. Kairaranga. 13: 36-43.

[2] Laksono, Sony P., Qomariyah, dan Purwaningsih, Endang. 2011. Persentase Distribusi Penyakit Genetik dan Penyakit Yang Dapat Disebabkan Oleh Faktor Genetik Di RSUD Serang. Majalah Kesehatan PharmaMedika. 3 (2): 267-271.

[3] Abdullah, King. 2016. Down Syndrome. Saudi Arabia: The Patient Education Institute, Inc.

[4] Coughi, O. A., Topolski, F., Faria, L., Occhiena, C. M., Ferreira, N., Ferlin, C., dan Mendoca, M. 2016. Prevalence of Dental Anomalies in Permanent Dentition of Brazilian Individuals with Down Syndrome. The Open Dentistry Journal. 10: 469-473.

[5] Lantu, V., Kawengian, S., dan Wowor, V. 2015. Hubungan Status Gizi dengan Erupsi Gigi Permanen Siswa SD Negeri 70 Manado. Jurnal e-Gigi. 3 (1): 189-196.

[6] Shaweesh, A. I. 2012. Clinical Duration of Permanent Tooth Eruption in Jordanians. $J$. Stomat. Occ. Med. 5: 70-76.

[7] Gupta, Priya V., 2016. Pediatric Dentistry for Special Child. India: Jaypee Brothers Medical Publishers (P) Ltd.

[8] Lamfon, H., Fansa, H., Beyari, M., dan Khalifa M. 2015. The Prevalenve of Oral and Dental Anomalies in Mentally-Retarded Children in Holy Makkah Community. International Journal of Health Sciences and Research. 5: 317-324.

[9] Boka, V., K. Markopoulos A., dan Poulopoulos A. K. 2009. Tooth Eruption: Topical and Systemic Factors that Influence the Process. Balk J Stom. 13: 11-14.

[10]Wise, G., Yao, S., dan Henk, W. 2007. Bone Formation as a Potential Motive Force of Tooth Eruption in the Rat Molar. Clinical Anatomy. 20: 632-639.

[11]Wang, Yuanyuan, Zhao, Yuming, dan Ge, Lihong. 2015. Delayed Eruption of Permanent Teeth in an Adoescent With Down's Syndrome: A Case Report. J Med Cases. 6 (6): 277-278.

[12] Wise, G. dan Yao, S. 2006. Regional 
Differences of Expression of Bone Morphogenetic Protein-2 and RANKL in the Rat Dental Follicle. European Journal of Oral Sciences. 114: 512-516.

[13]Wise, G. 2009. Cellular and Molecular Basis of Tooth Eruption. Orthod Craniofac Res. 12: 67-73.

[14]Wang, R., Green, J., Wang, Z., Deng, Y., Qiao, M., Peabody, M., Zhang, Q., dan Shi, L. 2014. Bone Morphogenetic Protein (BMP) Signaling in Development and Human Diseases. Genes and Diseases. 1: 87-105.

[15]Simic, P. dan Vukicevic, S. 2007. Bone Morphogenetic Proteins: From Developmental Signals to Tissue Regeneration. European Molecular Biology Organization. 8 (4): 327-331.

[16]Miyazono, K., Kamiya, Y., dan Morikawa, M. 2009. Bone Morphogenetic Protein Receotors and Signal Transduction. The Journal of Biochemistry. 147 (1): 35-51.

[17]Chau, J., Leong, W., dan Li, B. 2009. Signaling Pathways Governing Osteoblast Proliferation, Differentiation and Function. Histology and Histopathology. 24: 15931606.

[18]Canalis, E., Economides, A., dan Gazzerro, E. 2003. Bone Morphogenetic Proteins, Their Antagonists, and the Skeleton. Endocrine Reviews. 24(2): 218-235.

[19] Joziasse, I., Smith, K., Chocron, S., Dinther, M., Guryev, V., Smagt, J., dan Cuppen, E. 2010. ALK2 Mutation in a Patient with Down's Syndrome adn a Congenital Heart Defect. European Journal of Human Genetics. 19: 389-393.

[20]Trotsenburg, A., Kempers, M., Endert, E., Tijssen, J., Vijlder, J., dan Vulsma, T. 2006. Trisomy 21 Cause Persistent Congenital Hypothyroidism Presumably of Thyroidal Origin. Mary Ann Liebert, Inc. 16 (7): 671680.

[21] Fort, P., Lifshitz, F., Bellisario, M., Davis, J., dan Lanes, M. 1984. Abnormalities of Thyroid Function in Infants with Down Syndrome. The Journal of Pediatrics. 104 (4): 545-549.

[22]Claret, C. Goday, A., Benaiges, D., dan
Cano, J. 2013. Subclinical Hypothyroidusm in The First Years of Life in Patients with Down Syndrome. Pediatrics Research. 73 (5): 674-678.

[23]Vestergaard, P. dan Mosekilde, L. 2002. Fractures in Patients with Hyperthytoifism and Hypothyroidism: A Nationwide FollowUp Study in 16.249 Patients. Thyroid. 12 (5): 411-419.

[24]Tuchendler, D. dan Bolanowski, M. 2014. The Influence of Thyroid Dysfunction on Bone Metabolism. Thyroid Research. 7: 1216.

[25] Mc Lean, R. dan Podell, D. 1995. Bone and Joint Manifestations of Hypothyroidism. Seminars in Arthritis and Rheumatism. 24 (4): 282-290.

[26]Jara, L., Ondarza, A., dan Valenzuela, C. 1993. The Sequence of Eruption of the Permanent Dentition in A Chilean Sample With Down's Syndrome. Archs Oral Biol. 38: 85-89.

[27]Kochhar, R. dan Richardson, A. 1998. The Chronology and Sequence of Eruption of Human Permanent Teeth in Northern Ireland. International Journal of Pediatric Dentistry. 8: 243-252.

[28]Leung, K., Johannsson, G. Leong, G., dan Ho, K. 2004. Estrogen Regulation of Growth Hormone Action. Endocrine Reviews. 25 (5): 693-721.

[29]Torrado, C., Bastian, W., Wisniewski, K., dan Castells, S. 1991. Treatment of Children with Down Syndrome and Growth Retardation with Recombinant Human Growth Hormone. J Pediatr. 119: 478-483.

[30]Lee, C. dan Proffit, W. 1995. The Daily Rhythm of Tooth Eruption. Am J Orthod Dentofac Orthop. 107: 38-47.

[31]Rose, S., Municchi, G., Barnes, K., Kamp, G., Uriarte, M., Ross, J., Cassorla, F., dan Cutler, G. 1990. Spontaneous Growth Hormones Secretion Increase during Puberty in Normal Girls and Boys. Journal of Clinical Endocrinology and Metabolism. 73 (2): 428-435. 